\title{
THE ACCELERATING EFFECT OF CALCIUM AND OTHER CATIONS ON THE CONVERSION OF FIBRINOGEN TO FIBRIN ${ }^{1}$
}

\author{
By OSCAR D. RATNOFF AND ALBERT M. POTTS \\ (From the Departments of Medicine and Surgery, the Western Reserve University School of \\ Medicine, and University Hospitals, Cleveland, Ohio)
}

(Submitted for publication September 8, 1953; accepted October 26, 1953)

Whether the presence of calcium ions alters the rate at which fibrinogen is transformed to fibrin has been disputed repeatedly since Hammarsten first showed that solutions of thrombin clotted fibrinogen in the presence of oxalate salts (1). Most recently, Stefanini (2) reported that calcium salts inhibited the clotting of fibrinogen by thrombin. On the other hand, Seegers and Smith (3), Rosenfeld and Jánszky (4), and Biggs and Macfarlane (5) offered evidence that calcium accelerated the conversion of fibrinogen to fibrin by thrombin.

The problem was reexamined, using preparations of plasma and fibrinogen which had been depleted of cations other than sodium through the use of ion exchange resins. Certain cations, including calcium, shortened the clotting time in all but the highest concentrations tested. The effects described could be demonstrated only when the ionic strength of the mixtures was maintained at a constant level, so that the action of specific ions could be differentiated from the influence of the total ionic strength of the medium.

\section{METHODS}

Plasma was prepared by centrifuging human blood for 10 minutes at $10,500 \mathrm{rpm}$. in a Sorvall SS-1 centrifuge (rim diameter 9 inches) at $-5^{\circ} \mathrm{C}$., using lusteroid centrifuge tubes coated with desicote (Beckman). The blood was drawn through a No. 18 needle, coated with tri (2-hydroxyethyl) dodecyl ammonium chloride, ${ }^{2}$ into a silicone-coated syringe. The supernatant plasma, obtained without the use of an anticoagulant, was shaken for 10 minutes with one-third its volume of Amberlite resin, IRC 50, which was in the sodium phase at $\mathrm{pH} 7.7$. The resin was removed by centrifugation at room temperature for 10 minutes at $2,500 \mathrm{rpm}$ in an International centrifuge, Model SBV, Size 1. Such plasma, which was

1 This study was supported by a research grant (P.H.S. No. G3619) from the National Institutes of Health of the U. S. Public Health Service.

2 Armour Needle Coating Solution was obtained through the courtesy of the Armour Laboratories, Chicago. depleted of cations other than sodium, did not clot spontaneously at room temperature.

Human fibrinogen was prepared by a modification of Holmberg's method (6) described earlier (7), and was dissolved just before use in $0.10 \mathrm{M}$ sodium chloride solution. In different preparations, between 60 and 93 per cent of the protein was coagulable. Bovine fibrinogen, 3 prepared by the method of Ware, Guest, and Seegers (8), was dissolved in $0.15 \mathrm{M}$ sodium chloride solution and sufficient distilled water to make the concentration of sodium chloride approximately isotonic. The dried bovine fibrinogen contained $0.9 \mathrm{Gm}$. of sodium chloride for each $3.1 \mathrm{Gm}$. of protein. A portion weighing $100 \mathrm{mg}$. was dissolved in $2.6 \mathrm{ml}$. of water and $17.4 \mathrm{ml}$. of $0.15 \mathrm{M}$ sodium chloride solution, and was then filtered through Whatman No. 1. filter paper before use. The concentration of coagulable protein in solution averaged $300 \mathrm{mg}$. per 100 $\mathrm{ml}$., but the concentration varied by as much as $50 \mathrm{mg}$. from preparation to preparation. In any given experiment, the same solution of fibrinogen was used throughout.

The chloride salts of various cations were dissolved in distilled water in a concentration of ionic strength 0.3 , and diluted serially with water or with sodium chloride solution, as indicated. 4

Commercial bovine thrombin 5 was dissolved in $0.15 \mathrm{M}$ sodium chloride in a concentration of 1,000 National Institutes of Health (N.I.H.) units (3) per ml., and stored at $-20^{\circ}$ C. until used.

The solutions of fibrinogen, thrombin, and sodium chloride were treated with the amberlite resin in the same manner as the plasma.

The clotting time of mixtures of plasma or fibrinogen, thrombin, and the salt to be tested was measured at $37^{\circ} \mathrm{C}$. in pyrex tubes with an internal diameter of $8 \mathrm{~mm}$. The time when the contents of the tube jelled was recorded as the end point.

The concentration of fibrinogen was determined by a method described previously, in which fibrinogen is converted to fibrin by thrombin, and the tyrosine-like activity of the fibrin is then determined colorimetrically, using

${ }^{8}$ Bovine fibrinogen was obtained through the courtesy of Dr. Walter Seegers, Detroit.

4 To calculate the ionic strength of a solution of electrolytes, the molar concentration of each ion is multiplied by the square of its valence and the sum of the products thus obtained is then divided by two.

s Bovine thrombin'was obtained through the courtesy of Parke, Davis and Company, Detroit. 
TABLE I

The effect of calcium on the coagulation of human plasma by thrombin *

\begin{tabular}{|c|c|c|c|c|c|}
\hline \multirow[b]{2}{*}{$\begin{array}{c}\text { Total ionic strength } \\
\text { Final } \\
\text { concentration } \\
\text { of calcium ions } \\
\mathbf{m M} / \text { liter }\end{array}$} & \multicolumn{5}{|c|}{ Clotting time (sec.) } \\
\hline & .0 .10 & 0.125 & 0.15 & 0.175 & 0.225 \\
\hline $\begin{array}{c}0 \\
0.25 \\
0.50 \\
1.0 \\
2.1 \\
4.1 \\
8.2 \\
16.5 \\
33.3\end{array}$ & $\begin{array}{r}31 \\
19 \\
16 \\
14 \\
12 \\
9 \\
6 \\
7 \\
\end{array}$ & $\begin{array}{r}32 \\
23 \\
20 \\
15 \\
14 \\
10 \\
8 \\
7 \\
\end{array}$ & $\begin{array}{r}32 \\
23 \\
20 \\
16 \\
13 \\
10 \\
9 \\
8 \\
9\end{array}$ & $\begin{array}{r}32 \\
25 \\
22 \\
17 \\
14 \\
12 \\
10 \\
9 \\
10\end{array}$ & $\begin{array}{l}33 \\
26 \\
23 \\
20 \\
17 \\
16 \\
15 \\
12 \\
13\end{array}$ \\
\hline
\end{tabular}

* Clotting time of mixtures of $0.2 \mathrm{ml}$. each of human amberlite-treated plasma, bovine thrombin (10 N.I.H. units per $\mathrm{ml}$.) and calcium chloride. The ionic strengths were adjusted by the addition of appropriate amounts of sodium chloride to the solutions of thrombin and calcium.

the Folin-Ciocalteau reagent (9). In this method, the reagents are mixed in a tube containing crushed glass. The tube is agitated during clotting so that the fibrin which forms adheres to the crushed glass. This permits separation of the fibrin by simple centrifugation, with the result that washing of the clot is greatly facilitated.

The amount of calcium bound to fibrin was measured by studying clots formed from human fibrinogen and bovine thrombin in the presence of calcium chloride labelled 6 with $\mathrm{Ca}_{2}$. In one such experiment (in quadruplicate) a volume of $3 \mathrm{ml}$. of fibrinogen solution containing approximately $1.9 \mathrm{mg}$. of coagulable protein was mixed with $1 \mathrm{ml}$. of labelled calcium-chloride solution and $1 \mathrm{ml}$. of bovine thrombin solution ( 200 N.I.H. units per ml.). The final concentration of $\mathrm{CaCl}_{2}$ was $0.016 \mathrm{M}$; total radioactivity in the $5 \mathrm{ml}$. mixture was $0.1 \mu \mathrm{c}$. The

${ }^{6} \mathrm{Ca}$ " was obtained from the Oak Ridge National Laboratory, Oak Ridge, Tennessee. reagents were mixed in graduated centrifuge tubes each containing approximately $0.2 \mathrm{ml}$. of crushed pyrex glass (60 to 100 mesh) as measured by the displacement of fluid. The tubes were swirled during the clotting process so that the fibrin which formed adhered to the ground glass. The tubes were then centrifuged for 3 minutes at 2,000 rpm. and the supernatant fluid was decanted. The fibrin clot was then stirred thoroughly with $5 \mathrm{ml}$. of $0.15 \mathrm{M}$ sodium chloride solution and recentrifuged. This process was carried out for a total of ten times for one pair of tubes and twenty times for the other. Finally, the protein precipitate was dissolved in $1 \mathrm{ml}$. of $2.5 \mathrm{~N} \mathrm{NaOH}$ on the water bath, the solution neutralized to phenol red with $1.0 \mathrm{~N} \mathrm{HCl}$ and made up to $5 \mathrm{ml}$. with water.

Suitable aliquots were taken of the original supernatant, the subsequent washes, and the final protein solution in order to determine the calcium content by measurement of radioactivity. A $1 \mathrm{ml}$. aliquot of the dissolved residue was also taken for determination of protein as described above. The aliquots for radioactivity were evaporated to dryness under an infra red lamp in 1 inch dishes and $\mathrm{Ca}{ }^{\mathrm{w}}$ activity was determined with a thin mica window Geiger tube for the active samples and a windowless gas flow counter (Nuclear Measurements Co., Indianapolis) for the weak samples. The windowless counter was the more sensitive by a factor of 6.5 . The self-absorption correction was less than 3 per cent in all cases and could be ignored. Counts were converted to micrograms of calcium by comparison with values obtained for aliquots of the original solutions counted at the same time as the unknown. The ratio between calcium and fibrin was calculated on the assumption that the molecular weight of fibrin is 550,000 , a value between the reported estimates of 460,000 (10) and $700,000(6)$.

\section{RESULTS}

The influence of calcium ions on the clotting time of mixtures of human plasma and thrombin, at varying ionic strengths, is recorded in Table $\mathrm{I}$.

TABLE II

The effect of bivalent and trivalent cations on the coagulation of human plasma by thrombin $\dagger$

\begin{tabular}{|c|c|c|c|c|c|c|c|c|c|}
\hline \multirow{2}{*}{$\begin{array}{c}\text { Final } \\
\text { concentration } \\
\text { of cations } \\
(M / \text { liter })\end{array}$} & \multicolumn{9}{|c|}{ Clotting time (sec.) } \\
\hline & 0.033 & 0.016 & 0.008 & 0.004 & 0.002 & 0.001 & 0.0005 & 0.00025 & $\mathbf{0}$ \\
\hline $\begin{array}{l}\mathrm{CaCl}_{2} \\
\mathrm{SrCl}_{2} \\
\mathrm{BaCl}_{2} \\
\mathrm{MgCl}_{2} \\
\mathrm{MnCl}_{2} \\
\mathrm{CoCl}_{2} \\
\mathrm{NiCl}_{2} \\
\mathrm{HgCl}_{2} \\
\mathrm{CuCl}_{2} \\
\mathrm{FeCl}_{2}\end{array}$ & $\begin{array}{l}5 \\
5 \\
6 \\
7 \\
7 \\
* \\
* \\
* \\
* \\
*\end{array}$ & $\begin{array}{l}6 \\
7 \\
6 \\
6 \\
5 \\
* \\
* \\
* \\
* \\
*\end{array}$ & $\begin{array}{l}7 \\
8 \\
7 \\
8 \\
6 \\
* \\
* \\
* \\
* \\
*\end{array}$ & $\begin{array}{r}7 \\
9 \\
9 \\
10 \\
7 \\
9 \\
* \\
* \\
* \\
*\end{array}$ & $\begin{array}{r}9 \\
13 \\
12 \\
14 \\
8 \\
9 \\
* \\
* \\
* \\
*\end{array}$ & $\begin{array}{r}12 \\
16 \\
16 \\
16 \\
12 \\
13 \\
* \\
* \\
* \\
21\end{array}$ & $\begin{array}{r}15 \\
18 \\
17 \\
19 \\
17 \\
20 \\
16 \\
* \\
* \\
20\end{array}$ & $\begin{array}{l}18 \\
21 \\
20 \\
21 \\
21 \\
22 \\
20 \\
29 \\
18 \\
22\end{array}$ & 24 \\
\hline
\end{tabular}

† Clotting time of mixtures of $0.2 \mathrm{ml}$. of human amberlite-treated plasma, bovine thrombin (10 N.I.H. units per ml.) and the chloride salts. The final ionic strength of the mixture was 0.15 .

* No clot due to precipitation. 
TABLE III

The effect of monovalent cations on the coagulation of human plasma by thrombin*

\begin{tabular}{lccccccc}
\hline \hline \multirow{2}{*}{$\begin{array}{c}\text { Final } \\
\text { concentration } \\
\text { of cations } \\
(M / \text { liter })\end{array}$} & $\mathbf{0 . 1 0}$ & $\mathbf{0 . 0 5}$ & $\mathbf{0 . 0 2 5}$ & $\mathbf{0 . 0 1 2 5}$ & $\mathbf{0 . 0 0 6 2}$ & $\mathbf{0 . 0 0 3 1}$ & $\mathbf{0}$ \\
\hline$n y y y y y y y_{\mathrm{NH}} \mathrm{Cl}$ & 15 & 17 & 21 & 22 & 25 & 28 & 28 \\
$\mathrm{LiCl}$ & 22 & 23 & 25 & 26 & 26 & 29 & \\
$\mathrm{KCl}$ & 26 & 25 & 26 & 28 & 28 & 29 &
\end{tabular}

* Clotting time of mixtures of $0.2 \mathrm{ml}$. of human amberlite-treated plasma, bovine thrombin (10 N.I.H. units per ml.) and the chloride salts. The final ionic strength of the mixture was 0.15 .

At each concentration of calcium tested, the clotting time was shorter the lower the total ionic strength. When the ionic strength of the final mixture was held constant, the clotting time was shortened progressively by increasing the concentration of calcium ions, reaching a minimum at a concentration of approximately $0.017 \mathrm{M}$, and lengthening slightly at twice this concentration. The same result obtained when bovine fibrinogen was used instead of human plasma.

The effect of other bivalent ions and of certain monovalent and trivalent ions was measured in the same way. Representative experiments, at ionic strength 0.15 , are recorded in Tables II and III. Potassium and lithium ions accelerated the clotting of plasma slightly at the highest concentrations tested, but the clot accelerating effect of ammonium ions was appreciable. Mercuric, cupric, cobaltous, nickelous, and ferric chlorides accelerated the clotting of plasma by thrombin in low concentrations, but caused precipitation, presumably of proteins, in higher concentrations. The other bivalent cations tested-strontium, barium, magnesium, and manganese-were about as effective as calcium ions in shortening the clotting time. Again, the

TABLE IV

The calcium content of fibrin formed in the presence of calcium*

\begin{tabular}{lcccr}
\hline $\begin{array}{c}\text { Final } \\
\text { concen- } \\
\text { tration of } \\
\text { calcium }\end{array}$ & $\begin{array}{c}\text { No. of } \\
\text { washes }\end{array}$ & $\begin{array}{c}\text { Calcium } \\
\text { in washed } \\
\text { clot } \\
\mu g .\end{array}$ & $\begin{array}{c}\text { Protein } \\
\text { in washed } \\
\text { clot } \\
\text { mg. }\end{array}$ & $\begin{array}{r}\text { Moles } \\
\text { Ca per } \\
\text { mole } \\
\text { proteint }\end{array}$ \\
\hline $0.016 \mathrm{M}$ & 10 & 16.4 & 1.94 & 102 \\
& 20 & 2.9 & 1.86 & 19
\end{tabular}

* Calcium and fibrin content of a mixture of $3 \mathrm{ml}$. of human fibrinogen, $1 \mathrm{ml}$. of $0.08 \mathrm{M} \mathrm{CaCl}$, and $1 \mathrm{ml}$. of bovine thrombin ( $200 \mathrm{~N}$.I.H. units per $\mathrm{ml}$.). The solution of fibrinogen was 86 per cent coagulable.

+ The assumed molecular weight of fibrin was 550,000 .
TABLE $V$

Decrease in calcium content of successive washes *

\begin{tabular}{cccc}
\hline \hline $\begin{array}{c}\text { Super- } \\
\text { natant } \\
\text { No. }\end{array}$ & $\begin{array}{c}\text { Calcium } \\
\text { in wash } \\
\text { \% total }\end{array}$ & $\begin{array}{c}\text { Super- } \\
\text { natant } \\
\text { No. }\end{array}$ & $\begin{array}{c}\text { Calcium } \\
\text { in wash } \\
\text { \% total }\end{array}$ \\
\hline 1 & 100 & 6 & 0.43 \\
2 & 6.6 & 7 & 0.15 \\
3 & 1.9 & 8 & 0.07 \\
4 & 0.5 & 9 & 0.13 \\
5 & 0.23 & 10 & 0.14
\end{tabular}

* Calcium content of the supernatant fluid of successive washes of a clot formed from $1 \mathrm{ml}$. of $0.08 \mathrm{M} \mathrm{CaCl}_{2}$ and $1.0 \mathrm{ml}$. of bovine thrombin (200 N.I.H. units per ml.).

clot accelerating effect of the ions studied was the same when bovine fibrinogen was used instead of plasma.

It has been demonstrated that the characteristics of the clot which forms when fibrinogen reacts with thrombin differ in the presence and absence of calcium (11-14). A study was made to determine whether appreciable quantities of calcium were bound to fibrin when a mixture of fibrinogen and radio-calcium was clotted by thrombin, and the clot washed repeatedly with sodium chloride solution (Table IV).

There was a marked difference between the calcium/protein molar ratio after twenty washings as compared to ten washings. This ratio was found to be extremely inconstant from experiment to experiment and appeared to be partly a function of the initial calcium/protein ratio and of the number of washings. Thus in one experiment where the initial ratios were 333,1950 and 12,500 the final ratios were $4.6,26$, and 42 , respectively.

The results of typical serial washings as shown in Table $\mathrm{V}$ are of interest. The first wash reduces the calcium by a whole order of magnitude and the second wash by half this amount. Washes 3 to 5 remove rapidly decreasing amounts of calcium but from the fifth to the tenth wash the amount of calcium removed is essentially constant.

\section{DISCUSSION}

The effect of calcium ions on the clotting time of mixtures of fibrinogen or plasma and thrombin has been studied repeatedly, with conflicting results. It is probable that the confusion has arisen from a failure to control the ionic strength of the reaction mixture. The substitution of calcium ions for sodium ions appeared to shorten the clotting 
time of mixtures of plasma or fibrinogen and thrombin. Other bivalent ions were also effective unless precipitation of protein occurred. When potassium, lithium, or ammonium ions were substituted for sodium, the clotting time was shortened, but to a lesser extent than with equimolar concentrations of bivalent ions.

The mechanism by which bivalent ions exerted their effect is not understood. Previously, it was shown that the concentration of calcium did not affect the amount of fibrin which resulted from the reaction of fibrinogen and thrombin (7). During the last few years, experiments by Robbins (11), Laki and Lóránd (13) and others have demonstrated that the solubility of fibrin formed in the presence of calcium is different from that formed in its absence. Fibrin formed in the absence of calcium is soluble in weak hydrochloric acid or sodium carbonate and in urea. On the other hand, fibrin formed in the presence of calcium is insoluble in these solutions. Moreover, the tensile strength of clots formed in the presence of calcium is greater than that of clots formed in the absence of this cation $(11,14)$.

The nature of the bond between calcium and fibrin has been studied by the use of radiocalcium. Repeated washings of the calcium-fibrin clot removed essentially constant amounts of calcium each time after the first 5 washings (Table V). If one were dealing with a highly insoluble precipitate of calcium proteinate, with the calcium bound to the protein by polar linkages, this is the type of behavior one might expect. The rapid decrease in calcium in washings 1 to 5 would represent the removal of occluded material and the constant values in washings 5 to 10 would be determined by the solubility product of the precipitate. However, if this were true, a stoichiometric amount of protein should have been removed in all washes after the fifth, the weight of the protein should have decreased, and the calcium/protein ratio should have remained constant. That this was not the case is demonstrated by the extreme instance of Table IV which contrasts the result of ten and twenty washings. It is seen that the protein stays essentially constant whereas calcium alone is lost and the calcium/protein ratio decreases fivefold.

The most likely conclusion compatible with this finding and the overall inconstancy of results in each experiment is that the chief force operative in holding calcium to protein is a moderately strong adsorptive one. Thus, washings 1 to 5 remove occluded $\mathrm{Ca}^{++}$and washings 5 to 10 remove adsorbed ion without removing a corresponding amount of protein. In view of these considerations it would be extremely difficult to postulate a specific calcium-protein compound as the basis for clot formation.

The concentration of diffusible calcium in human serum, about $2.5 \mathrm{mEq}$. per liter, is sufficient to accelerate appreciably the clotting time of mixtures of plasma and thrombin. This makes it seem likely that the effect described occupies an important rôle in the normal process of blood clotting. The data which have been presented emphasize once again the importance of ionic strength and of ionic composition in determining the rate of clotting. These factors must be controlled rigidly in any in vitro study of coagulation.

\section{SUMMARY}

When ionic strength was maintained constant, calcium and certain other cations accelerated the conversion of fibrinogen to fibrin by thrombin. Studies with labelled calcium indicate that this acceleration of clotting is not accompanied by the formation of a firm bond between the calcium ions and the fibrin clot.

\section{ACKNOWLEDGMENT}

Thanks are due to Miss Joan Colopy and Miss Doris Goodman for their technical assistance.

\section{REFERENCES}

1. Hammarsten, O., Ueber die Bedeutung der löslichen Kalksalze für die Faserstoffgerinnung. HoppeSeyler's Ztschr. f. physiol. Chem., 1896, 22, 333.

2. Stefanini, M., Studies on the rôle of calcium in the coagulation of the blood. Acta med. Scandinav., 1950, 136, 250.

3. Seegers, W. H., and Smith, H. P., Factors which influence the activity of purified thrombin. Am. J. Physiol., 1942, 137, 348.

4. Rosenfeld, G., and Jánszky, B., The accelerating effect of calcium on the fibrinogen-fibrin transformation. Science, 1952, 116, 36.

5. Biggs, R., and Macfarlane, R. G., Human Blood Coagulation and Its Disorders. Oxford, Blackwell Scientific Publications, 1953. 
6. Holmberg, C. G., Studies on the splitting of fibrin under the influence of fibrinolysin from haemolytic streptococci. Ark. Kemi, Minerol. och Geol., 1944, 17A, No. 28.

7. Ratnoff, O. D., Studies on a proteolytic enzyme in human plasma. VIII. The effect of calcium and strontium ions on the activation of the plasma proteolytic enzyme. J. Exper. Med., 1952, 96, 319.

8. Ware, A. G., Guest, M. M., and Seegers, W. H., Fibrinogen: with special reference to its preparation and certain properties of the product. Arch. Biochem., 1947, 13, 231.

9. Ratnoff, O. D., and Menzie, C., A new method for the determination of fibrinogen in small samples of plasma. J. Lab. \& Clin. Med., 1951, 37, 316.
10. Oncley, J. L., Scatchard, G., and Brown, A., Physicochemical characteristics of certain of the proteins of normal human plasma. J. Phys. and Coll. Chem., 1947, 51, 184.

11. Robbins, K. C., A study of the conversion of fibrinogen to fibrin. Am. J. Physiol., 1944, 142, 581.

12. Wagreich, H., and Tarlov, I. M., Studies on the strength of fibrinogen-thrombin clots. Arch. Biochem., 1945, 7, 345.

13. Laki, K., and Lóránd, L., On the solubility of fibrin clots. Science, 1948, 108; 280.

14. Ferry, J. D., Miller, M., and Shulman, S., The conversion of fibrinogen to fibrin. VII. Rigidity and stress relaxation of fibrin clots; effect of calcium. Arch. Biochem., 1951, 34, 424. 